\title{
THE CULTURAL AND HISTORICAL SIGNIFICANCE OF MALOPO RITUAL: A PEDI PERSPECTIVE
}

\begin{abstract}
Indeed, the implicit hypothesis that "there is little possibility, if any, for the Pedi traditional healers to experience the supernatural form of healing without performing music and dancing to it" raises the issue of "What makes the dance potent as a healing therapy?" or 'What is the role of music in such healing processes?'. This article is a result of a guided investigation carried out in order to answer these questions. The primary sources for data collection were literature reviews, informal interviews, observations and recordings. During the study, informal discussions with traditional healers and their trainees revealed that participation in malopo rituals enables community members to inherit their music tradition. The impression created during interviews and observations was that Pedi traditional healers perform malopo songs to communicate with the ancestors. The results suggest that malopo rituals are aimed at enriching the personal and social life of the Pedi community.
\end{abstract}

\section{INTRODUCTION}

There is a growing emphasis in present-day religious practice that is designed to help people find healing from the sickness of mind, heart, soul, and body. This is a return to the original practice of Christianity. Only in recent times did we tend to overlook the fact that religion carried on healing activities for centuries. The word "pastor" derives from the Greek word Poimen meaning "shepherd" or "'overseer". The word relates to spiritual care or guidance of a congregation. Pastoral care often involves nurturing and caring for the weak within the body. Typically, nurturing pastors prefer a one-on-one ministry. Visiting the sick, shut-ins, caring for a small group, or comforting those who suffer are all classic functions of a nurturing pastor. Paul explains, for example, that a man aspiring to serve

Dr. M.E.K. Lebaka, Postdoctoral Research Fellow, Department of Old Testament Studies, Faculty of Theology, University of Pretoria, Pretoria 0002. E-mail: edwardlebaka@gmail.com. 
as an overseer or elder in the church "must be well thought of by outsiders" and by church members (1 Tim. 3:6-7). This means that a person appointed to serve as pastor must be a man with specific spiritual and moral qualities and must prove himself before he can be considered by the church to serve as pastor or elder. In modern times, however, man made the false assumption that it is impossible to harmonise the teachings of the Bible with what is called "science" and so the healing emphasis of religion was abandoned almost entirely by materialistic science. At present, however, the close association of religion and health is increasingly recognised.

Historically, there is far greater assumption that music and culture are related, maybe not inextricably, as many commonly assume. The following question concerns us in this instance: Why do so many theories and aesthetics of music resist that assumption? Above all, why does the historiography of Western art music, which includes historical musicology, music theory, ethnomusicology, and popular-music studies, cling to the opposed intuitive assumption that music and culture are separate? I want to suggest that one reason for the resistance to accepting the relatedness of music and culture results from the paradoxical unwillingness to admit to the full range of cultural content that music holds.

Currently, the cultural study of music asks different questions, ones that accept the relation of music to religion, region, race, class, gender, politics, ethnicity, belief, identity, money, power, and the production of knowledge. Attempts to capture the variegated experiential dimensions of music are now attracting increasing interest. In this article, our questions comprise music as a commodity of lived experience, as social practice, and as cultural symbol. Finally, it is the author's view that any music can function within any cultural context, if, of course, it is in the interest of producers and consumers to make it do so. The following question remains, nonetheless: Just where does the cultural work of history end and does the performance of any music from an African perspective prove the significance of music in African life and thinking?

\section{DIFFERENT PERSPECTIVES}

Indigenous music, which is described by Mindoti (2005:40) as a unifying force (in performance), forms part of a corpus of indigenous African musics that have been quite extensively researched in terms of musical components and performance practice in their primary contexts (see, for example, Jones 1959; Nketia 1962, 1974; Akpabot 1971; Kwami 1989; Agawu 1995). Whilst some commentators have focused on the theory and 
philosophy of theory in ethnomusicology, Ashenafi Kebede (1982:12), in his discussion of music in North Africa, argues that:

Traditional music is ordinarily performed by the common people, not by the professionally trained [literary] musicians; its repertory consists of material that has been passed down through the generations by means of oral tradition, by word of mouth.

Music experts often donate to the training of community members who wish to become masters on certain instruments and who play principal musical roles in ensembles. Chernoff (1979:3), Nzewi (1977:70) and Kofie (1994:3) provide accounts of how they studied and mastered techniques that enabled them to participate in musical discourse with indigenous African music experts. Chernoff (1979:4-9) shares his research experiences in Ghana and argues that music helps objectify the philosophical, religious and moral systems of the society. He suggests that "Music is essential to our [lives]" and that a village, which has no music or musicians, is said to be dead and is not a place where man can live. Ruth Stone (2002:58) argues that a practical music-situation is an "Event as object" of ethnomusicological research study. Sharing her experience, she remarks:

Throughout my career, I have focused my research on the musical event. Here I have found a conceptual place where sound and behaviour are created, appreciated and critically evaluated. There is a great scope for study within this focus.

\section{MALOPO RITUAL}

\subsection{Malopo tradition}

The term "tradition" 1 has been a slippery one when applied to various musical vernaculars, but, for our purposes, it may be defined as a set of transmission processes, not a specific repertoire of pieces or of style characteristics. A song, tune or story is traditional because, regardless of its origin, it has come to be learned, taught and passed on orally and in the memory. "Traditional malopo music", then, is a body of repertoires and of performance practices that are learned, taught and passed on like fashion.

1 Tradition: noun (1) the transmission of customs or beliefs from generation to generation. (2) a long-established custom or belief passed on in this way. (3) an artistic or literary method or style established by an artist, writer, or movement, and subsequently followed by others. Origin Latin, from tradere "deliver, betray" (Compact Oxford Dictionary accessible at http://www.askoxford.com/ concise_oed). 
Learning to play malopo music teaches not only skills but also appropriate perspectives and social behaviours. In this sense, the tradition - the repertoire of tunes, instrumental techniques, ensemble procedures, and expectations of decorum and conduct - itself recreates the context it requires, not only for performance, but also for pedagogy.

\subsection{Malopo music as culture}

Sekhukhune is a district that is endowed with a very rich musical heritage. Though, there are certain features and factors that bind the people together as Pedi people, several other factors and features differentiate one group from another. In malopo ritual, specifically, Pedi people are bound together in a related music tradition. Basically, malopo music is ethnic bound.

With the apparently clear distinction between tangible and intangible culture, music defies categorisation. Whereas its elements, the attributes that characterise sound, are intangible, its material is tangible. It is, therefore, tangible and intangible, a wholesome cultural experience. In several forums, we speak of our cultural heritage as opposed to active culture. Where culture is a people's way of life, it is understood that it is not static. The challenges of life necessitate innovations to bring about survival of individuals. The current beliefs, attitudes and practices regulate behaviour, thereby defining the active culture. Yet innovations do not spring out of a vacuum. They evolve from practices, beliefs and attitudes, a world view that characterises a people. This rich backdrop to current thinking lives on in physical sites and structures, objects and folklore.

Indigenous ${ }^{2}$ knowledge systems represent both national heritage and national resources. 'Indigenous' refers in the root, to something natural and innate. It is an integral part of culture (Oehrle 2001:102).

Malopo music is an indigenous knowledge system. It is a cultural expression - indeed the expression and reflection of Pedi culture. Through it, the past is re-lived, the present savoured and the future projected. The essential values of the Pedi culture are embedded in the culture's music, its content, processes and roles. Malopo music is the manifestation of a community's lifestyles and aspirations. That they sing shows that they are. What they sing opens their world to others, telling what they are. The way they sing tells of their philosophies - how they sing tells how

2 In its verb form, indigenization means "to cause to have indigenous characteristics: adapt to indigenous conditions of practices" (an excellent way of indigenizing what would otherwise remain a foreign system). Hence, indigenization is defined as the action or process of substituting a previously foreign system with a local one. 
they are. Through the type, content and procedures of music-making in a community, its existence, world view and nature are broadcast effectively.

Malopo ritual is then the best medium for understanding a Pedi culture. Through malopo ritual, the Pedi culture's socially significant occupations are practised. Through the procedures of music learning and teaching, the Pedi culture's values are reflected. One finds information in the content of its material, which reveals the identity and interests of the community. The community's ways are exposed in its inherent processes. The ethos and significance of the Pedi community are expressed from its role in the community's existence. Despite the impact of modernisation, malopo music is still regarded as a means whereby Pedi people perceive the present and reflect on their past experience, while projecting into the future.

\section{PHILOSOPHY OF PEDI RELIGION}

\subsection{Developing values}

Pedi people engage with malopo ritual, because they find it in some way meaningful, rewarding, or exciting - whether from an aural perspective or some broader behavioural or social point of view. Rituals in the Pedi culture are often intertwined with music. They manage fraught occasions in human lives and present organised occasions for emotional deployment where, again, it makes no sense to draw a division between thought and feeling. In the Pedi society, musical performances have been viewed as occasions for exploiting the encompassing capacity of sound to arrange a sense of communitas, of trance, or of transformation from one state to another.

Pedi traditional music encompasses performance techniques, styles, listening, form, theory, interpretation and history. It also gives the performers access to opportunities of musical expression and communication through the creation and performance of music within an indigenous Pedi context. It prepares performers for participation in community life. Pedi traditional music contributes to the holistic development of the performers. It develops creative, interpretative and analytical skills, and it also contributes towards personal growth and cultural affirmation of Pedi musical practices.

\subsection{Historical significance}

The historical context for malopo ritual is in an informal, often crossgenerational gathering. The members may participate by playing, singing and dancing. These sessions, rooted in a sense of cultural identity, participation and sharing, have followed the Pedi throughout the diaspora. Pedi 
traditional healers have found through them ways to recreate traditional contexts and behaviours, even in unfamiliar physical or economic settings. Such environments are not the standard paradigm of classroom education, but I believe that learning to play malopo music in the traditional way, avoiding the intrusion of alien teaching models, techniques or resources, provides individuals with skills and musical/social insights that cannot be passed on via notation or in the classroom.

\subsection{Cultural relevance}

Involvement with malopo ritual induces a physical-psychological-mental process in the Pedi society. Through hearing the mental process results in sound discrimination and perception. In learning, there is an aesthetic process involved in working with sound selection and organisation. Analysis leads to understanding and assimilation, which lead to application of what is known in music creation, an analytical-creative process. Yet in performance, there must be co-ordination and relation of the sound structures with particular gestures and actions. It is an associative process. Participants receive knowledge during malopo ritual, because the music conveys information - through sound and text.

\subsubsection{Humanism}

African religion scholars, notably Mbiti (1969), Busia (1964) and Idowu (1973), have emphatically asserted that the world of man and woman in Africa is imbued and replete with immanent spiritual beings, spirits, the living-dead or the spirits of the ancestors in conjunction with mystical power, magic, benevolent and diabolical spirits. At the head of the spiritual world is the Supreme Being or God. He is the autobiography of the universe, the forces of nature and human beings. The human being, a creation of God, is imbued with His spirit; hence, the spirit of man.

Every human person is believed in Africa to have non-dichotomous physical and spiritual aspects. The physical aspect is the body that is seen. The spiritual aspect is invisible, but observable. Man's spirit serves as a link between the human person and the spirit world. Hence, human beings are in a sense considered spiritual entities. The spirit of man is perceived as the essentiality of the human person(s). The spirits of the human persons are considered observable in their actions and words in the world. As Opata (2000:88) puts it:

The spirit in every being is made manifest in our eyes, the countenance, and in all bodily movements and gestures. Our appearance, our 
words, our actions are never greater than ourselves, for the soul is our house; our eyes its windows; and our words its messengers.

\section{About music-making in Africa, Chernoff lends credence to Nzewi's assertion when he states that}

we should be conscious of the fact that music making is above all an occasion for the demonstration of character (Chernoff 1979:64).

The philosophy ${ }^{3}$ of humanism thus is the way the African community seeks to use music to imbue human-being-ness in solving life problems. This is the way Africans seek to bring up the inexperienced to experience music (i.e., to make sense of and give form and meaning to music) as profound human idea, emotions and feelings. To achieve these, the development of creative potential and imaginative capacity is woven into music-making as a way of life. Indigenous Pedi music education ${ }^{4}$ is a process of engaging the individuals socially in music performance as a primary site for the production of knowledge. Every person is raised, to a large extent, by the process of socialisation. Through this process, they perceive music as a way of ennobling human life, and music performance as a process of conducting crucial issues of community living. It imbues humanness and an unbounded way of searching for meaning in life

3 The term "philosophy of religion" is therefore a relative newcomer to the philosophical lexicon, even though philosophical speculation of things religious goes back to the very beginning of the history of philosophy (Hick 1983; Pattison 2001). The term "philosophy of religion" (German: Religions philosophie), indicating a critical philosophical discipline exclusively concerned with the phenomenon of religion as a whole, appeared for the first time in the writings of G W F Hegel (Pattison 2001:79). As an independent form of philosophical inquiry, "philosophy of religion" therefore only really came into its own - and freed from the determinative constraints of dogma - after philosophy as such was alleged to have fallen into disrepute in biblical studies when, late in the eighteenth century, history replaced it as the main auxiliary discipline in biblical interpretation.

4 In the indigenous Pedi music education system, there is no point in the life cycle at which the creation of musical awareness could be said to be "complete". Music educational and social processes are indissolubly linked and take place within contexts in which members of society relate to each other, their environment, the land and spirit. It is made to relate to wider human concerns and interest. It is involved in their wholeness of being. Apart from the music training that is aimed at producing the specialized musicians, traditional Pedi music education, lifelong, is broad-based. This is rationalized to enable individuals function musically in the society in a holistic form. 


\subsubsection{Communalism}

In traditional Africa, music and community are close. Community, to Africans, consists of the living, the dead, and the unborn. The living ones are those who are in existence in this world. The dead are understood as the ancestors. Ancestors are community members who have lived well, died well, become ancestral spirits because full burial and funeral rites were accorded to them. Ancestors are the dead who are believed to be still alive and who are forming an integral part of the community in the world of spirits. They are referred to, therefore, as "the living dead" as these are called in contemporary African scholarship. The ancestral land is regarded, in Africa, as one of the sources of new community members. Ancestors, thus, are the unborn human-children. Human-children are good progenitors that return. A binding factor among community members is the ability to trace their origins easily to the same ancestral fatherhood or motherhood. What is more, every African community has a central place where members congregate for meetings, ceremonies, rituals, festivals and music performances. The place, generally known as the village square or village common ground, provides the space for validating, regenerating or commemorating the "communally binding and viable mythological concepts and covenants" (Nzewi 1978:123).

Mbiti (1969:2) views the African spirit of communalism as "closeness of living because each person belongs to others and in turn, is belonged to by others". To be an African entails belonging to the community, actively participating in, and contributing to all the activities of the community for the concrete benefits of both the individual and the entire community. To Africans, "the idea as well as the goal of art is community-oriented" (Nzewi 1997:26). Art in any form, whether oral or not, in visual arts, music, dance, drama, mime or in the crafts, is an alternative in the imagination to the reality around human beings. Art is, therefore, a rationalised mediation of life. So is music, which, in Africa, is viewed in terms of its relationship to the total art complex and not as an isolated phenomenon. In African community, all art is integrated with life and with each other. Hence, music and life are close.

In traditional Pedi society, members of the community become part by being the agentive centres of musical awareness and experience. $A$ goal of education, to which malopo ritual contributes, is the common good as well as communal sense. Preston (1997:16) defines the common good as "a coherent set of structural connections that promotes the interests of all members of society". Participation in music performance enables community members to inherit their music tradition. It also allows them to develop a communal sense and a sense of the common good. Malopo 
rituals are aimed at enriching the personal and social life of members of the community, cutting across age-sex categories, and social status roles and contributing to socio-cultural regeneration.

\subsubsection{Creativity}

While malopo ritual varies in its types, styles, and functions as well as uses from one ethnic group to the other (e.g., Xhosa, Ndebele, Zulu, Venda, Pedi, etc.), it has a basic underlying creative philosophy. With the human person's ability to create, creativity in general is considered an integral part of everybody's life. Thus, Pedi people believe that creative potential is innate in every person. Moreover, human beings are the conduits of musical creativity. In Africa, musical creativity is considered part of "the ancestral legitimation through which flow the life-force ... that drives the world and makes it live" (Davidson 1969:25).

Life is conceptualised as a cosmic cycle, or what Modum (1979:88) calls "the myth of eternal return". What this means is that for traditional Africans, they feel that in making or recreating music, which is essential to their life, they are repeating acts done by supernatural beings at different mystical times. According to this way of thinking, they feel that anytime they are making music, they are repeating and participating in creation. Put differently, Africans view participation in music-making as a way of integrating selves into the cosmogenic pattern.

Therefore, music-making involves learning the why and how of musical creativity. Musical creativity revolves around "making musical sense and making musical meanings" (Nzewi 1997:25). It involves learning to generate, to select and to make original musical utterances in relation to the inherited tradition and the ongoing musical contexts. Musical creativity involves knowing why, when and how to shape the ongoing music performance in ways that is contextually, situationally, artistically, socially and personally significant. This is so, because the real-life drama provides the resource for creative musical activities in Africa. The logic of this artistic vision is that music in Africa is a communal human creation for human purposes. As such, creative possibilities are endless as human needs are insatiable. However, musical output is deemed creative only when it passes sociopersonal validation.

A number of strategies for developing musical creativity in Africa are identifiable in literature. ${ }^{5}$ These include parody (Hutcheon 1988:35),

5 "Parody", according to Hutcheon "allows ironic signalling of difference at the very heart of similarly paradoxically indicating both cultural continuity and change, authority and transgression, involving both creator and partaker in 
signifying (Gates 1988:64), improvisation (Gates 1988:64) and performancecomposition (Nzewi 1997:68). These strategies apply regardless of the musical medium (instrumental or vocal). They have been the major ways of immersing, inducting and initiating Africans into their musical ancestry.

\subsubsection{Holism}

Scholars have recently been preoccupied with understanding the African world view, and the consensus tends to be that African metaphysics is holistic (Teffo \& Roux 2002:164-165). Generally, it is stated that Africans perceive the universe as comprising two distinguishable, but inseparable worlds - the visible and the invisible. Holism, the principle of appropriating things from many perspectives, underlies the entire African metaphysics. ${ }^{6}$ The holistic orientation to the understanding of reality, among the traditional Africans, makes it difficult to have boxed up units of discourse. Music features strongly in the holistic conception of the African universe. Traditional African music education, for example, is conceptualised as a unity of performance and transmission. Every time music is performed, it is being taught. And every time it is heard, it is being learnt. As it is being taught and learnt, the essential values of a culture it reflects are transacted and transmitted. The actual transfer of indigenous music from elders to young ones usually takes place through performance. As Finnegan (1970:2) observes:

participatory hermeneutics" (Hutcheon 1988:35). Signifying involves revising "that which is received, altering the way the past is read, thereby redefining one's relation to it" (Gates 1988:64). Gates (1988) defines improvisation as "repetition with revision". Drewal (1992) sees it more specifically "as moment-to-moment manoeuvring based on acquired in-body techniques to achieve a particular effect and/or style of performance". However, Nzewi says, improvisation is "an absolute/cerebral exploration of the sheer musical possibilities of a known musical theme and/or format" (Nzewi 1997:68). Performance - composition is "a mediation of continuity and conformity in a creative situation, i.e. a superstructural fleshing of the fish-bone to propel creative continuum in historical time and terms" (Nzewi, 1997:68).

6 Holism is a dominant principle in the practice of traditional African music education. Traditional music education encourages members of society to engage in mass musical knowing through performance-participation as well as within the context of other forms of artistic experience (dance, drama, poetry, and so on). In this way, they find themselves engaging their whole personalities in the whole web of beliefs, concepts, traditions and standards that give personal expression to their enquiring and imaginative minds. This enables members of society to relate to one another more completely and competently, sharing their inner imaginative lives in ways that enhance their musical lives and power of communication or interaction. 
there the connection between transmission and very existence is a much more intimate one, and questions about the means of actual communication are of first importance.

Abstractly embodied in malopo music are the values and ideals, the customs and beliefs most cherished by the community, as well as the inculcation which is considered an essential prerequisite for proper socialisation and integration within the group. By the subtle use of the influence of music, which is a product of the imagination, the Pedi traditional healers enable the interaction between the visible and the invisible; the musical process and the product; the formal and informal processes of music learning/teaching; the traditional healer and the trainee; as well as between the individual and the community. Thus, malopo music conceptualises the African quintessence of holism. In the holistic African world view, the notion of man is focused on the human being (human person), human life and human values, the expression of which is found in the human person's attempt to find meaning and sustenance in the world through interaction (communication), work and play. As Opata explains:

\begin{abstract}
By interaction is meant not only conventional, verbal and dialogic communication but also both ritual communication and participation in group work or play. By work is meant any type of activity whose immediate benefit is not leisure or recreation. Work is the foundation on which man builds his daily life and the source from which he draws the specific dignity which is proper to him. Play is any human activity whose immediate goal or result is the provision of recreation or leisure (Opata 1992:98).
\end{abstract}

In the Pedi society, the human person who makes music in the appropriate way finds human worth and significance in music a meaningful way of interacting. As the human-persons-traditional-healers make music, they give expression to their value systems and use malopo songs. They do it as a spiritual phenomenon, to evoke some spirits to participate in human affairs. They also use music, as a spirit that operates through sound energy, to evoke, coerce, control and titillate thinking, feelings, emotions, movements and actions in human others. Hence, malopo music in a Pedi context is not simply a medium of communication. It is also a metaphysical principle for manipulating cosmic forces. Above all, music also embodies some code of conduct in forms of delineating musical systems of a people, how to use certain forms of musical elements, when to use them, and who must use them. All these form part of the Pedi musical tradition and holistic training of the human person. ${ }^{7}$

7 Holistic music education, in which members of society creatively interpret sound qualities and patterns from Pedi musical tradition within the rich context of life itself, ensures the psychosocial unity of the individual and the social. 


\section{PHILOSOPHICAL ARGUMENTS}

Historically, each group of people assigns specific roles to its aural expressions, but some may be more special than others. An example is the existence of malopo rituals in the Sekhukhune area and the absence of the same in the Western settings. Knowing that, although objects and phenomena may exist in different cultures, yet are perceived differently, it is imperative to appreciate each community's view of music. Since different roles are assigned to music by different societies, can it really be viewed in the same way? Though universal, music is not uniform. There are many varieties and just as many ways of responding and creating because of it.

The development of individuals' creative musical abilities to the highest possible level is woven into music-making. The creative musical growth of every personality is helped by encouragement and affirmation of one another in situations where there are opportunities for everyone to participate and contribute to the perpetuation of the musical tradition. On performance occasions, every level of creative musical ability is put into best possible use through the development of singing skills, instrumental skills, as well as interpretive and critical skills. These enable individuals to understand socially the various idioms of creativity and conventions of musical presentation and how phonofacts are appreciated. Expert musicians, on their own, drawing upon their creative intelligence, use parody, signifying, improvisation and performance-composition to make music a way of understanding African life, having a direct knowledge of music, and cultivating a mastery of musical making.

\section{SOME CONCLUDING THOUGHTS}

From this study, it is evident that Pedi people believe that music in itself is healing. To them, music is an explosive expression of humanity. It is something we are all touched by. No matter what culture we are from, everyone loves music.

This article opens some vistas for the need of a reorientation about the concept of music among the Pedi traditional healers. Every race has its own music. No music of a race is superior to the other. It is a common phenomenon to have elements of music from one culture present in another as a result of religion, migration, trade, or war. The contact may also lead to a hybrid of a new musical culture, but does not mean a subjugation of the musical culture. Traditional African music has suffered an identity crisis in the past century. This has been a result of globalisation that caused the adaptation and appropriation of African folk melodies. Religion has been 
one of the major charitable reasons for the fusing of musical cultures of different peoples.

In conclusion, I would like to recommend that the way to promote malopo music, in particular, and Pedi music, in general, to an international greatness is in the independent study of every musical subtype on its own merit. No music would then be favoured at the expense of others, but rather, every musical subtype would be understood as a factor of religious interfaith, unity, development and common identity.

\section{BIBLIOGRAPHY}

Agawu, V.K.

1995. African rhythm: A Northern ewe perspective. Cambridge: Cambridge University Press.

АкPAвот, S.E.

1971. Standard drum patterns in Nigeria. African Music 5:1.

BusiA, K.A.

1964. Purposeful education for Africa. Cambridge: Cambridge University Press.

Chernoff, J.M.

1979. African rhythm and African sensibility: Aesthetics and social action in African musical idiom. Chicago: Chicago University Press.

DAVIDSON, B.

1969. The Africans: An entry to cultural history. Longman: Oxford University Press.

DreWAL, M.T.

1992. The state of research on performance in Africa. African Studies Review 34(3):1-64.

FINNEGAN, $R$.

1970. Oral literature in Africa. London: Oxford University Press.

Gates, H.L.

1988. The signifying monkeys: A theory of Afro-American literary criticism. New York: Oxford University Press.

Hick, J.

1983. The philosophy of religion. $3^{\text {rd }}$ ed. London: Macmillan.

HUTCHEON, L.

1988. A theory of parody: The teaching of twentieth-century art forms. New York: Methuen.

IDowu, B.E.

1973. Towards an indigenous church. London: Lutherworth Press. 
JONES, A.M.

1959. Studies in African music. 2 vols. London: Oxford University Press.

Kebede, A.

1982. Roots of Black music. New York: Englewood Cliffs.

KWAMI, R.M.

1989. African drumming 1. Music file, Series 8, Issue 1, Unit 3. London: Stanley Thornes Publishers Limited.

KoFIE, N.N.

1994. Contemporary African music in world perspectives. Accra: Ghana Universities Press.

MBITI, J.S.

1969. African religions and philosophy. New York: Praeger Publishers.

MindOTI, K.

2005. Indigenous Kenyan cultural dances: A forgotten chapter in the school curriculum. East African Journal of Music 1:38-43.

Modum, E.P.

1979. Gods as guests: Music and festivals in African traditional societies. Présence Africaine 121:80-100.

NKETIA, J.H.K.

1962. African music in Ghana: A survey of traditional forms. Accra: Longmans.

1974. The music of Africa. London: Gollancz.

NzeWI, M.

1977. Master musicians and the music of ese, ukom and mgba ensemble in Ngwa, Igbo. Belfast: Queens' University, PhD Thesis.

1978. Some social perspectives of Igbo traditional theatre. The Black Perspective in Music 6(2):113-143.

1997. Teaching and learning of music in African culture. In: J. Bahr, \& V. Schutz (eds.) Musickunterricht heute (Place of Publication?: Publishers?). pp. 16-34.

Oehrle, E.

2001. Towards a philosophy of education through music in South Africa. Van Niekerk (ed.). PASMEC 2001:102-112.

OPATA, D.U.

1992. Essays on Igbo worldview. Nsukka: AP Express Publishers.

2000. Literature and the spirit of man. In: T. Chuta (ed.) Readings in African humanities (Owerri: Vivians and Vivians Publishers), pp. 16-34.

Pattison, G.

2001. A short course in the philosophy of religion. London: SCM Press. 
Preston, R.

1997. The common good. Epworth Review 24(1):12-20.

STONE, R.

2002. African music in a constellation of arts. In: The Garland Encyclopedia of World Music (1) (New York: Garland), pp. 2-12.

Tefro, L.J. \& Roux, A.P.J.

2002. Themes in African metaphysics. In: P.H. Coetzee \& A.P.J. Roux (eds.) Philosophy from Africa, a text of reading (Cape Town: Oxford University Press), pp. 161-174.

Keywords

Pedi tradition

Malopo

Ancestors

Healing
Trefwoorde

Pedi-tradisie

Malopo

Voorvaders

Genesing 